\title{
ПРОБЛЕМИ РОЗВИТКУ УКРАЇНСЬКОЇ НАЦІОНАЛЬНОЇ ШКОЛИ В ПЕРІОД КІНЦЯ ХІХ - ПОЧАТКУ ХХ СТ.
}

\author{
О. М. Кін \\ доцент кафедри загальної педагогіки і педагогіки вищої школи \\ Харківського національного педагогічного університету імені Г. С. Сковороди.
}

Період к. XIX - початку XX століття характеризувався підйомом громадського інтересу до вітчизняної літератури і науки в Україні. Зросла кількість науково-дослідних організацій, в яких працювала плеяда видатних учених. Вивчення історичних матеріалів показало, що багато хто з українських учених у цей період досягли всеросійської і навіть європейської популярності. Серед них: засновник київської школи теоретичної фізики М. О.Умов, харківські математики О. М. Ляпунов, В. А. Стеклов, В. Г. Імшенецький, хімік М. М. Бекетов, ембріолог О. О. Ковалевський, мікробіолог І. І. Мечніков та ін.

Передова наукова громадськість звертала увагу на роль університетів і наукових об'єднань у поширенні наукових знань. Так, М. Ф. Сумцов підкреслював, що наука — це основа благополуччя суспільства, його незалежності і прогресу, відзначав, що стан науки, іiі спрямованість і рівень переважно визначають основні закономірності і динаміку розвитку суспільства [143]. Вчений констатував, що народи, які відстають у науках, приречені на поразку і зникнення, оскільки стають неконкурентноспроможними.

У той же час важливе місце у складній структурі взаємозв'язку та впливу об'єктивних факторів розвитку суспільства відводилося освіті. Учені, педагоги, громадські діячі були переконані, що заклади освіти, насамперед - школа, мусять у вирішенні навчально-виховних завдань гармонійно поєднувати різнобічні інтереси: одночасно служити прогресу суспільства та високим ідеалам науки.

Необхідно відзначити, що в досліджуваний період школа була не здатна виконувати свої обов'язки, спостерігався нерівномірний розвиток науки і народної освіти. I якщо досягнення передової вітчизняної науки і культури не поступалися європейським того ж періоду, то стан справ у сфері освіти і просвітництва був майже трагічним $[1,2,4,8]$. Наука стала своєрідною елітною категорією, яка розвивалася в значному відриві від загальної народної культури і просвіти.

Як показало вивчення історико-педагогічної літератури $[1,2,4,8]$, значний занепад рівня письменності серед населення був викликаний рядом причин: поширенням кріпосного права на території України, русифікаторською політикою царського уряду, низьким рівнем економічного розвитку, неспроможністю існуючих шкіл і т. д. Так, на рубежі XIX-XX століть серед сільського населення рівень письменності дорівнював $20 \%$, у містах $-50 \%$, серед робітничих Києва і Харкова - 60 \% [4]. Як і раніше відчувався гострий дефіцит шкіл, існуючі школи відрізнялись досить низьким рівнем викладання, освіта дорослого населення практично не велась. А С. Ф. Русова в роботі «Націоналізація школи у різних народностей Росії» 1907 р. показала трагічні наслідки дефіциту шкіл у Полтавській, Чернігівській, Київській, Харківській, Волинській, Подільській, Катеринославській та Херсонській губерніях, де проживало майже $2 / 3$ українського населення. Особливо катастрофічною була ситуація з народними школами у Київській, Подільській, Волинській губерніях, де на початку ХХ століття не було земств.

Я. Ф. Чепіга (Зеленкевич), теж відзначав, що ніде так гостро не відчувався рецидив безграмотності, як в українських селах, де мешкала більшість українського населення [10]. Таким чином, успіхи народної освіти були досить скромними, країна мала недосконалу народну школу, особливо в селі.

Як показав аналіз історико-педагогічної літератури $[1,2,10,11]$, із середини XIX століття у громадськопросвітницькій діяльності української інтелігенції значне місце став займати рух за відродження національної школи в Україні. Неоднорідні за своїми ідейними позиціями громадсько-політичні і педагогічні діячі були єдині у розумінні необхідності реорганізації шкільної освіти.

Величезну роль для розвитку української школи зіграла просвітницька діяльність В. К. Винниченка, Б. Д. Грінченка, М. С. Грушевського, О. В. Духновича, І. І. Огієнка, С. Ф. Русової, Лесі Українки, І. Я. Франка, Я. Ф. Чепіги, Т. Г. Шевченка та ін. Велике значення для прогресу національної системи освіти та просвітництва, зміцнення і формування національної самосвідомості у справі національно-культурного відродження мала діяльність наукових і культурно-освітніх організацій і товариств, зокрема: гуртка «Просвіта», наукового товариства ім. Т. Г. Шевченка, Російського педагогічного товариства. Всі вони вели боротьбу за відкриття шкіл, гімназій та інших навчальних закладів, в яких би не тільки здійснювалося навчання українською мовою, але й панував би дух національного виховання.

Основною причиною незадовільної роботи існуючої школи в Україні педагоги і громадські діячі одностайно вважали русифікаторську політику самодержавства у цій галузі. Так видатний педагог, учений Б. Д. Грінченко у працях «Яка тепер народна школа на Вкраїні», 1896 р., «На беспросветном пути. Об украинской 
школе», 1905 р., «Якої нам треба школи», 1912 р. вказував на принципові недоліки існуючої української школи, системи освіти, навчання і виховання. Головним серед них було грубе порушення одного з найважливіших принципів педагогічної науки - принципу природовідповідності. Вчений був впевнений, що нівелювання цього принципу привело до денаціоналізації всіх сфер життя українського народу, у тому числі школи й освіти, і послужило причиною деформації мислення, світогляду, моральності народу.

Українські педагоги слідом за К. Д. Ушинським, вважали, що російська школа в Україні безсила, некорисна, оскільки гальмує розумовий і моральний розвиток особистості. Наприклад, П. А. Грабовский («Про розвиток шкільної освіти в Охтирському повіті Харківської губернії» 1885 р., «Дещо про освіту на Україні» 1897 р.) переконливо довів, що існуючі в Україні церковно-парафіяльні школи, які були зобов'язані поширювати основи письменності серед народу, насправді виявилися неспроможними вирішувати такі завдання і навіть шкідливими в справі народної освіти, тому що «сіють обмоскалення та темряву».

У Державному Архіві Харківській Області збережено текст промови члена Товариства Грамотності М. І. Міхновського, з якою він виступив на загальних зборах товариства 29 квітня 1901 року [9, с. 31]. Доповідач відзначав, що народна школа в Україні побудована на антипедагогічному принципі, вона «псує та спотворює психіку малоруської дитини, і з цього боку стає деморалізуючим фактором».

Для обгрунтування свого обвинувачення М. І. Міхновський звернувся до наукових принципів, сформованих ще А. Дистервегом, який довів, що навчання необхідно здійснювати від простого до складного, від відомого до невідомого. У російській школі, за переконанням доповідача, грубо порушувався цей принцип, мета навчання перетворювалася на засіб, і завдання навчання «вирішувалися за допомогою лише невідомих понять». Він також відзначав, що російська школа для дитини чужа і незрозуміла, процес читання не дає учням ніякого задоволення. Автор, підкреслюючи абсурдність і неспроможність російської школи, зазнав, що, навіть коли допитлива дитина захоче зрозуміти зміст прочитаного, вчителя, який зробив переклад, може бути звільнено інспектором школи за пояснення українською мовою.

Вивчення названих джерел, архівних матеріалів переконливо свідчить, що офіційна система освіти грунтувалась на релігійно-монархічній ідеології і ставила на меті виховання молодого покоління в дусі відданості російській державі, поваги до закону, любові до государя і вітчизни. Так, у Державному Центральному Історичному Архіві знаходиться документ, у якому повідомляється, що вся робота навчальних закладів повинна підпорядковуватись загальній ідеї «навчання підростаючого покоління істинам віри і моралі християнської для церковної освіти і щирої доброти» [ЦДІА, Ф.45, оп.1, од.3б. 2200, арк. 38]. Таким чином, русифікаторська політика в Україні гальмувала розвиток українських шкіл, становлення національної системи навчання та виховання.

Так, М. Ф. Сумцов узагальнив великий матеріал з історії, етнографії України та довів, що низький освітній рівень українського народу тісно пов'язаний з урядовою культурно-освітньою політикою Російської імперії. Головною причиною низькоефективного та непродуктивного шкільного навчання вважав «зросійщеність» (як він ії визначав) існуючої школи. Він писав: «Школа була холодною для розуму і серця дитини» [7, с.183]. Звертав увагу на те, що школа створювала для українських дітей серйозні проблеми і труднощі у навчанні, оскільки викладання велося винятково російською мовою, на чужому матеріалі: історія, географія, література України майже не вивчалися. «Чужа мова, чужа наука» — відзначав педагог. За існуючої системи навчання, коли знайомим із дитинства поняттям і явищам відповідали незнайомі слова, сприймати нову інформацію, осмислювати ії і відтворювати в системі незнайомих найменувань та назв було досить важко. У цих умовах інтелектуальний розвиток дітей, якісне поповнення їх знань, поширення ерудиції ставали практично неможливими.

Отже, школа в Україні була не тільки не корисною, але й шкідливою і навіть небезпечною. По-перше, існуюча школа не вирішувала свого першого та головного завдання - освіти дітей. По-друге, школа, спеціально пристосована урядом для знищення українського народу як самостійної духовної особистості, створювала серйозні перешкоди для формування та розвитку національної самосвідомості учнів. [5, с. 48]. Так, М Ф. Сумцов був упевнений, що саме існуюча система освіти значною мірою сприяла поширенню, так званої «малоруської ментальності» - виникненню в українському середовищі цілого класу так званих малоросів: чиновників, службовців та ін., які презирливо ставилися до рідної мови, культури, традицій. М. Ф. Сумцов називав таке явище «духовною еміграцією», і відзначав, що процес денаціоналізації займає все більші масштаби, проникає у всі структури українського суспільства: «Інтелігенція пішла геть від народу на послугу російському уряду і допомагала йому нищити українське життя» [7, с.148].

У той же час школа в Україні має всі підстави і можливості для плідної роботи на національному грунті, про що переконливо свідчать історія і культурно-педагогічні традиції української школи: здобутки Київської Русі, братерські українські школи, широко відома Києво-Могилянська академія, козацька система виховання і навчання.

Завдяки діяльності прогресивної української громадськості в Україні кінця XIX — початку XX століття було закладено основи для розвитку національного напряму в шкільній освіті, для відродження національної школи в Україні вважалося за необхідне, в першу чергу, здійснення викладання у школі рідною мовою. 
Зазначимо, що досить поширеною у досліджуваний період були концепції так званого гумбольдтіанства (пізніше: неогумбольдтіанства, етнолінгвістики), за ім'ям їі засновника В. Гумбольдта, дослідника в галузі мовознавства і філософії мови. Саме на його праці спирався український учений Я. Ф. Чепіга, повністю погоджуючись 3 ним з приводу того, що мова $є$ властивістю духовного розвитку нації і багато в чому визначає iї національний характер. За глибоким переконанням Я. Ф. Чепіги, мова нерозривно пов'язана із ментальністю нації, є яскравим показником індивідуальності цілої народності. Я. Ф. Чепіга підкреслював, що мова народу, яка має власну літературу, готові форми мислення, пов'язана з психологічним становленням нації, передає особливості долі і думок народу. Він писав: «Мова — то праця народного духу, його жива діяльність» [10, с. 105]. Тому використання російської мови у середніх школах вважав свідомим злочином проти нації, оскільки теорія про психологічні особливості кожної нації була в той час вже загальновідомою. Автор вказував, що «процес мислення зливається з нашою мовою, котра в кожної нації твориться віками, що національні риси мислення відбиваються на мові, літературі, взагалі на творчості» [11].

До прихильників етнолінгвістики також відносяться такі вчені, як Ф. Боас, Л. Вайсгербер, В. Вуедт, О. О. Потебня та ін. Можна стверджувати, що теоретико-методологічною базою зазначеного напряму став антропологічний підхід до мови, згідно з яким мова, свідомість, мислення, культурне і духовне життя людини і нації знаходяться в тісному взаємозв'язку. Філософськими джерелами такого підходу були ідеї та теоретичні розробки німецької класичної філософії (Г. Гегель, І. Гете, І. Кант, Ф. Шеллінг та ін).

Як показало вивчення робіт вчених і просвітителів досліджуваного періоду, теорія про зв'язок мови і мислення була досить поширеною та популярною серед прогресивної української інтелігенції. Наприклад, Б. Д. Грінченко розглядав навчання українською мовою, як необхідну умову розвитку української національної школи. Вчений підкреслював, що потреба виражати свої думки мовою, знайомою із раннього дитинства, обумовлена природною основою розвитку дитини, залежить від спадкових властивостей організму, типу нервової системи і природних функціональних якостей, що виникають ще у період ембріонального розвитку. Автор був переконаний, що «діти, що вчаться своєю рідною мовою, розумніші, більше в них хисту й думкою змолоду моторніші, ніж ті, кому затуркують голову мовою чужою» [24, с. 6].

Як показало вивчення історико-педагогічної літератури, архівних джерел досліджуваного періоду $[1,2$, $3,7,8,9]$ зневажливе ставлення до української мови було характерним не тільки для системи освіти, але і простежувалося в усіх сферах громадського життя. Започаткування цієї тенденції відбулося ще в II половині XVIII століття, саме тоді спостерігалося прискорення процесу розчинення української культури в російській. Українська мова одержала статус провінційної, поширилась теорія про доцільність використовування української мови тільки для гумористичних оповідань, історій, жартів і т. ін. [3, с. 8]. Як писав із цього приводу Б. Д. Грінченко: «Нашій українській мові нема ходу: вигнано іiі зі школи, з суду, з усіх державних і краєвих урядів, з церкви - скрізь... по школах школярів одучають, щоб по-своєму не говорити, і розказують їм, що українська мова, то хохлацька, мужицька, погана мова, що нею говорять тільки дурні хохли, а що путящий, розумний, освічений чоловік винен говорити московською мовою» $[1$, с. 41$]$.

Необхідно відзначити, що основним аргументом для гонінь української мови стало твердження про те, що українська мова - не окрема мова, а лише говірка. 3 цією точкою зору ніяк не могли погодитися українські вчені, письменники і суспільні діячі. Наприклад, М. С. Грушевський у роботах «Непорозумнішали», «Російська Академія наук про українську мову» доводив абсурдність таких припущень. Він відзначав, що навіть комітет міністрів визнав у 1905 р. шкоду заборони української мови, а ради Київського і Харківського університетів, київський генерал-губернатор, Російська Академія наук заявили, що заборону українського слова вважають шкідливою і пропонували їі негайно зняти.

М. Ф. Сумцов також доводив, що українська мова являє собою самостійне, незалежне філологічне утворення, бездоганне і закінчене з наукової точки зору. Підкреслював, що українська мова надзвичайно естетично багата, називав іï «головною річчю в житті кожного історичного народу» [6, с. 3]. Вчений провів грунтовне дослідження в галузі української мови та літератури, в якому спробував знайти відповіді на питання: «Як виникла мова, під впливом яких чинників формувалась і розвивалась, де іiі джерела, як співвідноситься сучасна мова із мовою древньою та народним говором, які основні говори і наріччя існують на Україні і як вони склалися?» Результати дослідження знайшли відображення у таких роботах: «Вага і краса української народної поезії» 1917 р., «Історичні зразки українського літературного єднання», 1918 р., «Нариси розвитку української літературної мови», 1918 р. та ін. Учений підкреслював, що незважаючи на те, що ці питання сугубо наукового характеру, проте, вони цікаві й актуальні для широкого кола громадськості, оскільки «у цих питаннях криється головна річ усієї національної справи» [6, с. 3]. Педагог розглядав різноманітні аспекти цієї проблеми на тлі та у взаємозв'язку з тими національно-мовними процесами, що відбувалися в Україні та за їі межами протягом усього процесу становлення та розвитку української мови.

Слід зазначити, що у досліджуваний період виділилися дві різні гіпотези з приводу доцільності використання рідної мови у школі. Представники першого напряму усвідомлювали необхідність застосування рідної 
мови у системі освіти, культурного життя і т. ін., але обмежувалися лише міркуваннями з цього питання, не виступали відкрито. Представники другого напряму активно наполягали на необхідності повернення освіти, науки, культури до української мови. Серед них такі відомі письменники, педагоги, вчені як Б. Д. Грінченко, С. Ф. Русова, Леся Украінка, І. Я. Франко.

Питання навчання рідною мовою стали предметом обговорення на різних з’їздах, у роботі деяких комітетів, громадських організацій.

Так, вивчення архівних джерел показало, що на загальних Зборах Товариства Грамотності в 1901 році, виступаючий із доповіддю М. І. Міхновський запропонував створити на ім'я Міністра Народної Освіти клопотання, яке б містило два положення:

1. Про введення до малоруських шкіл Харківської Губернії малоруської мови.

2. Про допущення до народних шкіл малоруських підручників, підготовлених до географічних, кліматичних і побутових умов місцевого населення [9, с. 34].

Питання про необхідність навчання українських дітей рідною мовою обговорювалося і на з'їздах народних

вчителів (починаючи ще 3 80-х років XIX століття), що проходили під керівництвом відомого педагога М. О. Корфа [3, с. 90]. 3 проханням до Міністерства Народної Освіти про дозвіл викладати в народних школах рідною мовою зверталися Чернігівське (1881р.) і Полтавське (1910 р.) земства. Також за навчання у народній школі рідною мовою висловлювалися Бердянський, Воронезький, Конотопський, Полтавський, Чернігівський сільськогосподарські комітети (1902р.), Чернігівське (1903р.), Вовчанське, Хотинське (1904 р.) повітові земства, Полтавська й Одеська міські думи (1905р.), Харківське Товариство Грамотності (1897р.), Санкт-Петербурзький комітет письменності, Московський агрономічний з’їзд (1901р.), Третій з'їзд російських діячів у галузі професійної і технічної освіти (Санкт-Петербург, 1903 р.), різноманітні вчительські курси, збори і т. ін. Так, у травні 1906 року за ініціативи Б. Д. Грінченка, С. Ф. Русової та ін. були здійснені заходи для створення Всеукраїнської вчительської спілки, одним із проектів спілки стала організація у червні-липні 1906 р. вчительських курсів з українознавства, на які прибуло понад 400 народних вчителів із Правобережної, Лівобережної, Слобідської України, Таврії [3, с. 171].

Проблеми національної школи були центральними у роботі курсів. Результатом стало прийняття 2 резолюцій, що стосувалися реформування освіти і школи в Україні та у яких, крім іншого, говорилося, що навчання повинно вестися рідною мовою. У 1906 р. курси з українознавства проходили також у Харкові, Катеринославі, Херсоні, Чернігові і т. ін.

Таким чином, питання реорганізації шкільної освіти, розбудови національної школи були предметом особливої уваги української інтелігенції, прогресивної педагогічної громадськості. Висновок про зв'язок між станом національної системи освіти та майбутнім розвитком всієї країни був поширеним і усвідомленим.

Педагоги, вчені, громадські діячі одностайно і переконливо доводили шкідливість існуючої школи в Україні, основними причинами ії незадовільної роботи вважали денаціональний характер освіти.

В основу концепції розвитку національної школи було покладено постулат самостійності української культури, нації, мови. Для відродження та розвитку української школи вважалося за необхідне: здійснення викладання у школі лише рідною мовою; введення до шкільної програми предметів, що вивчають українську історію, літературу, географію, прикладні мистецтва; розробку і видання українських підручників.

\section{Література}

1. Грінченко Б. Д. Чого нам треба. Львів, 1905.41 с.

2. Грінченко Б. Д. Якої нам треба школи. К.,1912. 6 с.

3. Зайченко I. В. Проблеми української національної школи в пресі другої половини XIX — поч. XX ст.: дис. ... докт. пед. наук: 13.00.01. К., 1996. 414 с.

4. Субтельний О. Україна: історія. К. : Либідь, 1994. 736 с.

5. Сумцов М. Ф. Вага і краса української народної поезії. Черкаси, 1917. 64 с.

6. Сумцов М. Ф. Нариси розвитку української літературної мови. Х., 1918. 97 с

7. Сумцов М. Ф. Слобожане. Історично-етнографічна розвідка. Х. : Союз, 1918. 224 с.

8. Сумцов Н. Ф. 25-летие историко-филологического общества при императорском Харьковском университете. Х., 1904. 12c.

9. ХДОІА, Фонд 200. «Правление Харьковского общество распространения в народе грамотности (1869 — 1920 гг.)», оп.1, од. зб. 251. «Доклад о народных школах».

10. Чепіга Я. Ф. Національність і національна школа // Проблеми виховання і навчання в світлі науки і практики. К., 1913. $125 \mathrm{c}$.

11. Чепіга Я. Ф. Читання з поясненнями в сучасній школі на Вкраїні // Світло. 1913. Кн.7. С.16. 